\title{
Fungsi Dan Arti Periklanan Televisi Dalam Menciptakan Minat Konsumen Produk Sabun Mandi Kecantikan
}

\author{
RONI ANDESPA \\ Sekolah Tinggi Ilmu Ekonomi Riau (STIE-RIAU) \\ Jln. HR. Subrantas 57 Panam Pekanbaru 28293 Telp. (0761) 63237 \\ E-mail : akbar_stier@yahoo.com
}

\begin{abstract}
The study was conducted in Tanah Datar, West Sumatra, Indonesia. With the aim of assessing the influence of the meaning and function of television advertising for beauty soap buying interest.With a sample of 200 consumer sof beauty bath soap products. The sampling technique used wasnon-probability sampling method with Convenience sampling. The results showed From the Model Summary tables hows the function and meaning of the advertising variables explain variable consumer buying interest at $54.9 \%$, while the rest of $45.1 \%$ is influenced by variables/factors outside of the study, in which the value $R=0.741$. Significant value of the variable function and meaning of advertising on buying interest to simultaneously show the sig. $0.000(<0.05)$ at level $\alpha=5 \%$. This shows that there is a significant influence of independent variables on the dependent variables simultaneously study. Significant value of the variable function and meaning of advertising to buy a partial interest in showing the value of $<0.05$ at $\alpha=5 \%$. This shows that there is a significant influence of independent variables on the dependent variables in partial studies.
\end{abstract}

Keywords: Meaningand Function of Television, Advertising, Beauty Soap, Buying Interest

Perkembangan media komunikasi mendorong banyak perubahan kearah yang positif bagi dunia usaha.Dengan teknologi yang semakin maju dan ditunjang dengan kemampuan masyarakat untuk menerima informasi dengan cepat, membuat penyampaian informasi terhadap suatu produk dan jasa meningkat baik dalam kualitas maupun jenisnya.

Periklanan merupakan bagian dari strategi pemasaran terutama sekali strategi promosi, dimana iklan merupakan cara untuk berkomunikasi dengan pasar dan juga merupakan salah satu faktor penentu untuk dalam suatu program pemasaran.

Pada prinsipnya keberhasilan program periklanan merupakan salah satu sokongan dalam menentukan efektivitas suatu program pemasaran. Bentuk-bentuk periklanan dapat dibedakan dengan tugas-tugas khusus meskipun secara umum mempunyai fungsi yang sama mempromosikan tentang suatu produk untuk memberikan informasi, merubah sikap atau mendorong orang untuk bertindak.

Pemilihan media promosi yang tepat sangat mempengaruhi terhadap keberhasi- lan kegiatan pemasaran, dengan media yang tepat akan membantu tercapainya tujuan promosi, yaitu terciptanya komunikasi yang baik dan lancar antara produsen dan konsumen.

Dari berbagai iklan barang-barang yang akan ditawarkan melalui iklan adalah produk yang akan dibeli dan untuk dikonsumsi masyarakat diantaranya adalah iklan sabun mandi kecantikan.

Tujuan mengiklankan produknya melalui media yaitu agar produknya dapat dikenal oleh konsumen atau masyarakat dan cocok untuk dijadikan pilihan seterusnya dan paling penting untuk membangkitkan keinginan konsumen untuk melakukan pembelian.Iklan sabun kecantikan tidak mau kalah dengan merk-merk lain dalam mengiklankan produknya melalui media, agar produknya dapat lebih dikenal oleh masyarakat luas.

\section{Pemasaran}

Pemasaran dan produksi merupakan fungsi pokok bagi perusahaan semua berusaha memproduksi dan memasarkan produk atau jasa untuk memenuhi kebutuhan kon- 
sumen. Pada saat ini kegiatan pemasaran mempunyai peranan penting dalam dunia usaha, istilah pemasaran ini diartikan sama dengan beberapa istilah, seperti: penjualan, perdagangan, dan distribusi.

Pemasaran merupakan konsep yang sangat menyeluruh sedangkan istilah yang lain tersebut hanya merupakan satu bagian, satu kegiatan dalam sistem pemasaran secara keseluruhan. Secara definitif pemasaran adalah sebagai berikut:

Pengertian pemasaran menurut William J. Stanton (1978 Pemasaran adalah sistem keseluruhan dari kegiatan-kegiatan bisnis yang ditunjukan untuk merencanakan, menetukan harga, mempromosikan, dan mendistribusikan barang dan jasa yang dapat memuaskan kebutuhan kepada pembeli yang ada maupun pembeli potensial.

Sedangkan menurut Kotler dan Armstrong (1997) Pemasaran adalah suatu proses sosial dan manajerial yang membuat individu dan kelompok apa yang mereka butuhkan serta inginkan lewat penciptaan dan pertukaran timbal balik produk dan nilai dengan orang lain.

Dari definisi diatas dapat diambil kesimpulan bahwa pada dasarnya kegiatan pemasaran meliputi:

a. Menentukan produk yang dibutuhkan oleh konsumen.

b. Merencanakan dan mengembangkan produksi, baik berupa barang atau jasa yang dapat memuaskan kebutuhan konsumen.

c. Menentukan harga, promosi dan distribusi

d. Mencari input dari konsumen maupun lembaga pemasaran untuk kebijaksanaan selanjutnya.

Jadi pemasaran merupakan suatu interaksi yang berusaha untuk menciptakan hubungan pertukaran yang ditujukan untuk memberikan kepuasan baik penjual maupun pembeli.

\section{Konsep Pemasaran}

Konsep pemasaran merupakan falsafah penting dalam perusahaan yang menyatakan keinginan pembeli adalah syarat utama bagi kelangsungan hidup perusahaan . Konsep pemasaran berorientasi pada kebutuhan dan keinginan yang didukung oleh pemasaran yang diarahkan kepada terciptanya kepuasan konsumen. Secara definitif konsep pemasaran adalah sebagai berikut: konsep pemasaran adalah sebuah falsafah bisnis yang menyatakan bahwa pemuasan kebutuhan konsumen merupakan syarat ekonomi dan sosial bagi kelangsungan hidup perusahaan (Swastha dan Irawan, 1997).

Sedangkan konsep pemasaran menurut Philip Kotler sebagai berikut: konsep pemasaran adalah kunci untuk meraih tujuan organisasi agar menjadi efektif dari pada para pesaing dalam memadukan kegiatan pemasaran guna menetapkan dan memuaskan (Kotler, 2001).

Konsep pemasaran tersebut disusun dengan memasukkan tiga elemen pokok yaitu:

1) Orientasi konsumen/pasar/pembeli

Pada dasarnya perusahaan yang ingin menerapkan orientasi konsumen ini harus:

a. Menentukan kebutuhan pokok dari pembeli yang akan dilayani dan dipenuhi.

b. Memilih kelompok pembeli tertentu sebagai sasaran dalam penjualanya.

c. Menentukan produk dan program pemasaranya.

d. Mengadakan penelitian kepada konsumen, untuk mengukur, menilai dan menafsirkan keinginan, sikap, serta tingkah laku mereka.

e. Menentukan dan melaksanakan strategi yang paling baik, apakah menitik beratkan pada mutu yang tinggi, harga yang murah atau model yang menarik.

2) Volume penjualan yang menguntungkan

Penjualan yang menguntungkan merupakan tujuan dari konsep pemasaran, artinya laba dapat diperoleh dengan melalui pemasaran konsumen. Dengan laba ini perusahaan dapat tumbuh dan berkembang dapat menggunakan kemampuan yang lebih besar pada konsumen, serta dapat memperkuat kondisi perekonomian secara keselu- 
ruhan.

Perilaku minat konsumen adalah ha-

\section{Perilaku Konsumen}

Perilaku konsumen dapat didefinisikan sebagai berikut, sebagai tindakan yang langsung terlihat dalam mendapatkan, mengkonsumsi dan menghabiskan produk dan jasa termasuk proses keputusan yang mendahului dan menyusuli tindakan ini (Engel, Roger, Miniard, 1994).

Dengan jelas terlihat bahwa definisi tersebut mengemukakan dua elemen penting yaitu (1) proses pengambilan keputusan dan (2) kegiatan Fisik, yang semua ini individu dalam menilai mendapatkan, dan mempergunakan barang-barang dan jasajasa ekonomis. Pada tahap-tahap awal dalam memahami dan mempelajari perilaku konsumen adalah menggambarkan model dan konsep perilaku konsumen.Salah satu yang sederhana yaitu black box model, menggambarkan bahwa perilaku konsumen dipengaruhi oleh rangsangan-rangsangan pemasaran yang dilakukan oleh pemasaran.

\section{Minat Konsumen}

Minat (intention) merupakan suatu kecenderungan untuk melakukan tindakan terhadap objek (Assael 1998, dalam Ikhwan Susila dan Faturrahman 2004).(Dharmmesta 1998, dalam Ferrinadewi dan Pantja, 2004) menjelaskan, minat terkait dengan sikap dan perilaku.

Minat dianggap sebagai suatu "penangkap" atau perantara antara faktor-faktor motivasional yang mempengaruhi perilaku, minat juga mengindikasikan seberapa keras seseorang mempunyai kemauan untuk mencoba.

Minat menunjukkan seberapa banyak upaya yang direncanakan seseorang untuk melakukan sesuatu dan minat berhubungan dengan perilaku.

Minat konsumen tumbuh karena suatu motif berdasarkan atribut-atribut sesuai dengan keinginan dan kebutuhannya dalam menggunakan suatu pelayanan produk, berdasarkan hal tersebut maka analisa mengenai bagaimana proses minat dari dalam diri konsumen sangat penting dilakukan. sil dari evaluasi terhadap merek atau produk. Tahapan terakhir dari proses tersebut adalah pengambilan keputusan secara kompleks termasuk menggunakan merek atau produk yang diinginkan, mengevaluasi merek atau produk tersebut pada saat digunakan dan menyimpan informasi untuk digunakan pada masa yang akan datang.

(Assael 1998 dalam Ikhwan Susila dan Faturrahman 2004) lebih lanjut menjelaskan, bahwa pada saat seorang konsumen melakukan evaluasi terhadap merek atau produk, konsumen cenderung akan menggunakan merek atau produk yang memberikan tingkat kepuasan tertinggi. Seorang pelaku di dunia pemasaran akan berusaha keras untuk mengukur minat dari konsumen, serta mengetahui faktor-faktor apa saja yang mempengaruhi minat tersebut.

Minat konsumen merupakan perilaku konsumen yang menunjukkan sejauh mana komitmennya untuk melakukan tindakan pembelian atau kegiatan penggunaan suatu produk.

Kebutuhan dan keinginan konsumen akan barang dan produk berkembang dari masa ke masa dan mempengaruhi perilaku mereka, dalam istilah asing perilaku konsumen sering disebut consumer behaviour, perilaku konsumen dapat didefinisikan sebagai kegiatan individu yang secara langsung terlibat dalam mendapatkan dan mempergunakan barang-barang dan produk termasuk didalamnya proses pengambilan keputusan pada persiapan dan penentuan kegiatan tersebut (Swastha,1990), perilaku konsumen dalam mengambil keputusan, mempertimbangkan barang dan produk apa yang akan di beli, dimana, kapan, bagaimana, berapa jumlah dan mengapa membeli produk tersebut.

Inti masalah mengacu pada minat konsumen.minat yang cenderung kurang kepada suatu produk, dan berkurangnya jumlah konsumen yang akan menggunakan produk tersebut.

Pemecahan masalah hal tersebut bisa memiliki sumber masalah pada pencitraan yang buruk dari perusahaan tersebut, 
promosi yang dilakukan perusahaan sangatlah kurang sehingga informasi tentang produk yang ditawarkan tidak sampai ke konsumen atau masalah kualitas pelayanan yang kurang memuaskan membuat konsumen cenderung enggan menggunakan produk tersebut.

Kesimpulan pembahasan tentang minat mengacu bahwa minat dapat didefinisikan sebagai suatu sikap dari seorang konsumen yang berupa kemauan untuk menggunakan atau mencoba suatu yang ditawarkan oleh perusahaan, bisa berupa produk atau produk.

Bigne (2005), Ekinci dan Hosany (2006), Alampay (2003), dan Rosen (1987) menjelaskan kecenderungan seseorang menunjukkan minat terhadap suatu produk atau produk dapat dilihat berdasarkan ciriciri:

1. Kemauan untuk mencari informasi terhadap suatu produk atau produk

Konsumen yang memiliki minat, memiliki suatu kecenderungan untuk mencari informasi lebih detail tentang produk atau produk tersebut, dengan tujuan untuk mengetahui secara pasti bagaimana spesifikasi produk atau produk yang digunakan, sebelum menggunakan produk atau produk tersebut.

2. Kesediaan untuk membayar barang atau produk

Konsumen yang memiliki minat terhadap suatu produk atau produk dapat dilihat dari bentuk pengorbanan yang dilakukan terhadap suatu barang atau produk, konsumen yang cenderung memiliki minat lebih terhadap suatu barang atau produk akan bersedia untuk membayar barang atau produk tersebut dengan tujuan konsumen yang berminat tersebut dapat menggunakan barang atau produk tersebut

3. Menceritakan hal yang positif

Konsumen yang memiliki minat besar terhadap suatu produk atau produk, jika di tanya konsumen lain, maka secara otomatis konsumen tersebut akan mencitrakan hal yang positif terhadap konsumen lain, karena konsumen yang me- miliki suatu minat secara eksplisit memiliki suatu keinginan dan kepercayaan terhadap suatu barang atau produk yang digunakan.

4. Kecenderungan untuk merekomendasikan

Konsumen yang memiliki minat yang besar terhadap suatu barang, selain akan menceritakan hal yang positif, konsumen tersebut juga akan merekomendasikan kepada orang lain untuk juga menggunakan barang atau produk tersebut, karena seorang yang memiliki minat yang besar terhadap suatu barang akan cenderung memiliki pemikiran yang positif terhadap barang atau produk tersebut, sehingga jika ditanya konsumen lain, maka konsumen tersebut akan cenderung merekomendasikan kepada konsumen lain.

\section{Indikator Minat Konsumen}

Indikator untuk minat dalam penelitian ini meliputi:

1. Kesediaan untuk membayar barang atau produk.

2. Menceritakan hal yang positif.

3. Kecenderungan untuk merekomendasikan.

\section{Periklanan}

\section{1) Pengertian Periklanan}

Periklanan merupakan bentuk presentasi dan promosi non pribadi tentang ide barang dan produk yang dibayar oleh sponsor tertentu. Menurut Nickels ada beberapa pihak yang menjadi sponsor, tidak hanya tertentu saja akan tetapi juga lembaga-lembaga non laba, seperti lembaga pemerintah (Swastha dan Irawan, 1997).

Iklan yang dipasang pada media-media tersebut dapat memberikan umpan balik kepada sponsor (berupa tanggapan) meskipun dalam tenggang waktu tertentu. Dalam kegiatan periklanan ini terdapat dua keputusan penting yang harus diambil, yaitu:

a. Menentukan iklan yang harus disampaikan kepada pasar yang di- 
tuju.

b. Memilih media yang paling sesuai.

\section{2) Tujuan Periklanan}

Tujuan periklanan adalah untuk mempertahankan dan meningkatkan penjualan produk (Kasali, 1995), antara lain adalah:
a. Mendukung program personal selling dan kegiatan promosi lain.
b. Mencari yang tidak dapat dicapai oleh salesmen dalam jangka waktu tertentu.
c. Mengadakan hubungan dengan para penyalur/distributor.
d. Memasuki daerah pemasaran baru/menarik pelanggan baru.
e. Memperkenalkan produk baru.
f. Menambah penjualan industri.

\section{3) Sasaran Periklanan}

Sasaran periklanan menurut Kasali (1995) adalah:

a. Mencari perhatian dan minat konsumen terhadap produk baru, teknologi baru dan perusahaan-perusahaan baru.

b. Meningkatkan para pembeli dan calon pembeli secara konstan tentang tersedianya produk-produk dan perusahaan yang ada, bagaimana perbandinganya dengan produk dan perusahaan lain.

c. Untuk meningkatkan perhatian dan kewaspadaan semua anggota saluran pemasaran tertentu tentang: produk tertentu, perbaikan-perbaikan produk, promosi khusus, kontes-kontes dan sifat lain pada tata kerja di perusahaan lain.

d. Melaksanakan peran penjualan produk dan ide-ide.

e. Mencapai audiensi secara terpilih.

f. Mengurangi disonasi para pembeli dan meniadakan ketidak puasan tertentu.

\section{4) Fungsi dan Arti Periklanan}

Fungsi dan arti periklanan menurut Kasali (1995) adalah:

a. Memberikan Informasi

Periklanan dapat menambah nilai pada suatu barang dengan memberikan informasi lebih banyak dari pada lainya, baik tentang barang, harga atau informasi lain yang mempunyai kegunaan bagi konsumen. Tanpa adanya informasi, orang segan atau tidak akan mengetahui banyak tentang barang. Disini periklanan ditujukan untuk memberitahu atau periklanan informasi

b. Membujuk atau mempengaruhi

Periklanan tidak hanya bersifat memberitahu kepada para pembeli-pembeli potensial dengan menyatakan bahwa suatu produk lebih baik dari produk lainya.Walaupun pada umumnya orang tidak ingin dibujuk atau didorong untuk membeli produk yang sudah jelas dapat memuaskan kebutuhan dan keinginan mereka. Apabila ada dua produk yang sejenis penjual akan mengeluarkan lebih banyak waktu dan tenaga untuk membujuk orang bahwa produknya lebih baik dari produk lain.

c. Menciptakan kesan

Dengan sebuah iklan orang akan mempunyai kesan tertentu tentang apa yang diiklankan. Dalam hal ini pemasang iklan selalu berusaha untuk menciptakan iklan sebaik-baiknya. Periklanan dapat menciptakan kesan pada masyarakat untuk melaksanakan pembeli secara rasional dan ekonomis penjual atau produsen berusaha untuk memberikan kesan pada konsumen bahwa produknya berbeda dengan produkproduk lain

d. Memuaskan keinginan

Sebelum memilih dan membeli produk, kadang-kadang orang lain diberitahu lebih dulu. Periklanan merupakan suatu alat yang dapat dipakai untuk mencapai tujuan itu sendiri berupa pertukaran yang saling memuaskan dan juga merupakan salah satu alat komunikasi yang sangat efisien bagi para penjual.

\section{5) Jenis periklanan}

Beberapa macam cara dalam periklanan dapat digolongkan atas dasar penggunanya memprogram periklanan. Dalam hal ini periklanan dapat digolongkan menjadi dua yaitu: 
a. Periklanan barang

Periklanan barang ini dilakukan dengan menyatakan pasar tentang produk yang ditawarkan.

b. Periklanan kelembagaan

Dilakukan untuk menimbulkan rasa simpatik terhadap penjual. Jadi periklanan ini menitik beratkan pada nama penjual atau perusahaan.

\section{6) Evaluasi Efektivitas Periklanan}

Pengendalian dan perencanaan iklan sangat tergantung pada efektivitas iklan, walaupun demikian jumlah penelitian mendasar tentang iklan ini sangatlah sedikit, kebanyakan ukuran efektivitas iklan bersifat terapan, yang berurusan dengan pelaksanaan iklan dan kampanye khusus. Biaya yang dikeluarkan oleh perusahaan untuk melakukan uji coba pendahuluan iklan-iklan yang ada jauh lebih sedikit yang dikerjakan untuk melakukan pasca evaluasi mengenai dampak iklan.Penyajian naskah iklan bisa saja dilakukan sebelum iklan sungguhan dipasang di satu media. Untuk menyusun kreasi yang kreatif dalam menentukan iklan ada beberapa tahap diantaranya:

a. Tahap perencanaan pesan (Massage Generation).

Suatu iklan haruslah dapat memberikan dorongan dan himbauan pada konsumen untuk merasa tertarik

b. Evaluasi seleksi pasar.

Pesan-pesan iklan tersebut diharapakan bisa membangkitkan selera dan keinginan yang eklusif, logis dan harus dapat menggambarkan produk yang utama, sehingga dari pesan-pesan melalui iklan tersebut konsumen dapat membuktikan kebenaranya.

Hendaknya pesan iklan disampaikan dengan gaya yang berbeda-beda seperti cuplikan kehidupan dan lain-lain. Baty Subakty ketua dewan kehormatan Persatuan Periklanan Indonesia, mengatakan bahwa (Subakty, 1994):

a. Tujuan komunikasi

Pesan iklan yang dikirim sebaiknya sederhana langsung dan mengandung keakraban. Dengan kriteria tersebut khalayak akan semakin mudah mengingat pesan, iklan ataupun produk yang ditawarkan.

b. Tujuan penjualan

Pesan iklan perlu didahului oleh kesan menghibur, menjual atau sebaliknya sebab pesan iklan yang ideal akan membuat khalayak mengidentifikasikan produk itu sebagai suatu yang ditunjukan pada konsumen.

Ada tiga pertimbangan untuk meningkatkan efektivitas periklanan:

a. Melakukan positioning

Disini diupayakan menciptakan kaitan yang sifatnya segera dan langsung dengan produk diiklankan dengan kekhasan yang dimiliki.

b. Gagasan atau ide-ide yang dikumpulkan mesti kuat hal ini mensyaratkan kreatifitas yang tinggi.

c. Pendekatan kepada khalayak mesti tepat.

\section{7) Televisi Sebagai Media Periklanan}

Televisi dapat digunakan sebagai sebuah media baik secara nasional maupun regional.Jenis kemasan yang ditawarkan oleh televisi adalah fleksibel, dari penyediaan waktu individual yang khusus sampai ke penjamin sebuah liputan khusus untuk kelompok sasaran tertentu perlu dicatat bahwa penggunaan televisi regional dapat memberikan kesan pada kelompok sasaran setempat. Bahwa kampanye dapat disampaikan adalah besar dan bersifat nasional kita dapat menggunakan saluran jangkuan khusus, yaitu kabel satelit yang banyak mencakup kelompok-kelompok peminat tertentu, saluran olah raga misalnya melalui media televisi, iklan televisi raksasa yang terpampang di jalan-jalan utama kerja dapat menarik minat dan perhatian para pelnggan (dan banyak orang lain) pada saat-saat mereka kebetulan melewati jalan-jalan utama.

Model yang digunakan di dalam penelitian adalah sebagai berikut: 


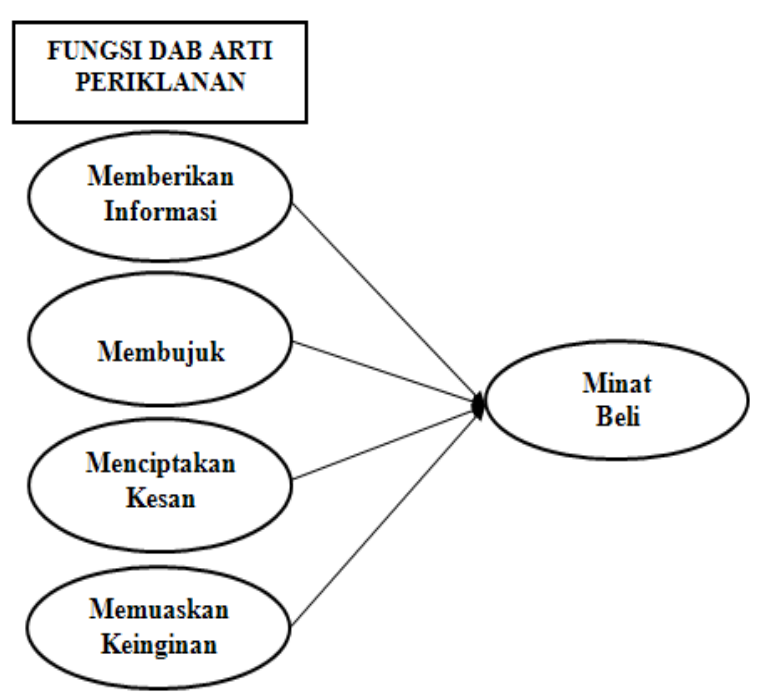

Gambar 1. Model Penelitian

Hipotesis dalam penelitian adalah sebagai berikut:

$\mathrm{H}_{1}=$ Diduga variabel-variabel fungsi dan arti periklanan iklan sabun mandi kecantikan mempengaruhi minat beli konsumen secara simultan.

$\mathrm{H}_{2}=$ Diduga variabel-variabel fungsi dan arti periklanan sabun mandi kecantikan mempengaruhi minat beli konsumen secara parsial.

\section{METODE}

Populasi yang digunakan adalah seluruh konsumen sabun mandi kecantikan di Tanah Datar, Sumatera Barat. Dimana Sampel dalam penelitan yang digunakan adalah sebanyak 200 konsumen yang ada, teknik pengambilan sampel yang digunakan adalah metode non probability sampling dengan Convenience sampling, mengingat dimana jumlah populasi yang cukup besar, maka setiap konsumen yang mudah untuk ditemui, dan rasanya bisa untuk menjadi sampel, maka berhak untuk menjadi responden. Hal ini dilakukan untuk diagnosis situasi secara cepat dan bersifat sederhana serta mudah, karena adanya keterbatasan waktu dalam penelitian.

Data yang digunakan adalah data primer yang diperoleh melalui penyebaran kuesioner kepada responden yang dijadikan sampel dengan pertanyaan tertutup dimana skala pengukurannya menggunakan skala 1 sampai dengan 5 (skala likert). Dimana angka 1 mewakili Sangat Tidak Setuju (STS) sampai dengan angka 5 mewakili Sangat Setuju (SS). Analisis data dilakukan dengan menggunakan analisis regresi berganda.

$$
\mathrm{Y}=\alpha+\beta_{1} \mathrm{X}_{1}+\beta_{1} \mathrm{X}_{1}+\beta_{1} \mathrm{X}_{1}+e
$$

Keterangan:

$\mathrm{X}_{1}=$ Memberikan informasi

$\mathrm{X}_{2}=$ Membujuk/mempengaruhi

$\mathrm{X}_{3}=$ Menciptakan kesan

$\mathrm{X}_{4}=$ Memuaskan keinginan

$\mathrm{Y}=$ Minat beli

$e=$ Epsilon/Nilai Sisa

\section{HASIL}

Setelah data kuesioner terkumpul, maka dilakukan pengolahan data dengan bantuan komputer. Dan didapat outputnya sebagai berikut:

Tabel 1. Output SPSS Model Summary Variabel Fungsi dan Arti Periklanan Terhadap Minat Beli

Model Summary

\begin{tabular}{|l|r|r|r|r|}
\hline Model & R & R Square & $\begin{array}{c}\text { Adjusted } \\
\text { R Square }\end{array}$ & $\begin{array}{r}\text { Std. Error of } \\
\text { the Estimate }\end{array}$ \\
\hline 1 & $.741^{\mathrm{g}}$ & .549 & .540 & .545 \\
\hline
\end{tabular}

a. Predictors: (Constant), Memuaskan Keinginan,

Menciptakan Kesan, Membujuk, Memberikan Informasi

Sumber: Data Primer, Olahan SPSS

Dari tabel Model Summary dapat dilihat nilai $\mathrm{R}$ Square menunjukan variabel fungsi dan arti periklanan mampu menjelaskan variabel minat beli konsumen sebesar $54,9 \%$, sedangkan sisanya sebesar $45,1 \%$ dipengaruhi oleh variabel/faktor di luar penelitian. Dimana nilai $\mathrm{R}=0,741$ artinya merupakan nilai kontribusi yangkuat darivariabel fungsi dan arti periklanan terhadap minat beli yaitu sebesar 74,1\% .

Tabel 2. Output SPSS Anova Variabel Fungsi dan Arti Periklanan Terhadap Minat Beli 


\begin{tabular}{|c|c|c|c|c|c|c|}
\hline \multicolumn{2}{|c|}{ Model } & $\begin{array}{l}\text { Sum of } \\
\text { Squares }\end{array}$ & $d f$ & Mean Square & $F$ & Sig. \\
\hline \multirow[t]{3}{*}{1} & Regression & 70.525 & 4 & 17.631 & 59.426 & $.000^{8}$ \\
\hline & Residual & 57.855 & 195 & .297 & & \\
\hline & Total & 128.380 & 199 & & & \\
\hline
\end{tabular}

a. Predictors: (Constant), Memuaskan Keinginan, Menciptakan Kesan, Membujuk, Nemberikan Informasi

b. Dependent Variable: Winat Beli

Sumber: Data Primer, Olahan SPSS

Dari hasil output komputer pada tabel 2 dapat dilihat nilai signifikan variabel fungsi dan arti periklanan terhadap minat beli secara simultan menunjukan nilai sig. $0,000(<0,05)$ pada tingkat $\alpha=5 \%$. Hal ini menunjukan bahwa terdapat pengaruh yang signifikan antara variabel independent terhadap variabel dependent penelitian.Maka hipotesis 1 dalam penelitian, "Diduga variabel-variabel fungsi dan arti periklanan iklan sabun mandi kecantikan mempengaruhi minat beli konsumen secara simultan", diterima.

Tabel 3. Output SPSS Coefficients Variabel Fungsi dan Arti Periklanan Terhadap Minat Beli

Coefficients $^{\mathrm{a}}$

\begin{tabular}{|c|c|c|c|c|c|c|}
\hline \multirow[b]{2}{*}{ Model } & & \multicolumn{2}{|c|}{$\begin{array}{c}\text { Unstandardized } \\
\text { Coefficients }\end{array}$} & \multirow{2}{*}{$\begin{array}{l}\text { Standardized } \\
\text { Coefficients } \\
\text { Beta }\end{array}$} & \multirow[b]{2}{*}{$t$} & \multirow[b]{2}{*}{ Sig. } \\
\hline & & $B$ & Sto. Error & & & \\
\hline 1 & (Constant) & .913 & .169 & & 5.399 & .000 \\
\hline & Memberikan nformasi & .237 & .059 & .304 & 4.037 & .000 \\
\hline & Membujuk & .129 & .049 & .176 & 2.625 & .009 \\
\hline & Menciptakan Kesan & 192 & .055 & .247 & 3.523 & .001 \\
\hline & Memuaskan Keinginan & .112 & .053 & .140 & 2.098 & .037 \\
\hline
\end{tabular}

Sumber: Data Primer, Olahan SPSS

Pada tabel Coefficients variabel fungsi dan arti periklanan terhadap minat beli, terlihat:

Variabel memberikan informasi terhadap minat beli nilai signifikannya adalah sig. $0,000 \quad(<0,05)$, dimana menunjukan pengaruh yang signifikan antara memberikan informasi terhadap minat beli konsumen.

Variabel membujuk terhadap minat beli nilai signifikannya adalah sig. 0,009 $(<0,05)$, dimana menunjukan pengaruh yang signifikan antara memberikan informasi terhadap minat beli konsumen.

Variabel menciptakan kesan terhadap minat beli nilai signifikannya adalah sig. 0,001 $(<0,05)$, dimana menunjukan pengaruh yang signifikan antara memberikan informasi terhadap minat beli konsumen.

Variabel memuaskan keinginan terhadap minat beli nilai signifikannya adalah sig. 0,037 $(<0,05)$, dimana menunjukan pengaruh yang signifikan antara memberikan informasi terhadap minat beli konsumen.

Maka hipotesis 2 "Diduga variabelvariabel fungsi dan arti periklanan sabun mandi kecantikan mempengaruhi minat beli konsumen secara parsial".Diterima dalam penelitian.

Dari table 3 juga bisa dilihat Bahwa terlihat konstanta $(\beta)$ sebesar 0,913 , koefisien $\left(\beta_{1}\right)$ sebesar 0,237 dan koefisien $\left(\beta_{2}\right)$ sebesar 0,129, koefisien $\left(\beta_{3}\right)$ sebesar 0,192 , dan koefisien $\left(\beta_{4}\right)$ sebesar 0,112 , sehingga dapat ditampilkan kedalam bentuk persamaan:

$$
Y=\alpha+\beta_{1} X_{1}+\beta_{2} X_{2}+\beta_{3} X_{3}+\beta_{4} X_{4}
$$

Jika diasumsikan dapat ditulis persamaan sebagai berikut:

$\mathrm{Y}=0,913+0,237+0,129+0,192+0,112$

Dari persamaan diatas dapat diartikan bahwa besarnya pengaruh memberikan informasi $\left(\mathrm{X}_{1}\right)$ terhadap minat beli sebesar 0,237 , ini berarti apabila variabel memberikan informasi ditingkatkan sebesar satu satuan variabel, maka minat beli akan meningkat sebesar 0,237 kali satuan variabel, dengan syarat variabel $\mathrm{X}_{2}, \mathrm{X}_{3}$ dan $\mathrm{X}_{4}$ tetap, dan apabila variabel memberikan informasi dimisalkan nol (tetap), maka variabel minat beli tetap ada sebesar konstanta 0,913.

Dari persamaan diatas dapat diartikan bahwa besarnya pengaruh membujuk $\left(\mathrm{X}_{2}\right)$ terhadap minat beli sebesar 0,129 , ini berarti apabila variabel membujuk/mempengaruhi ditingkatkan sebesar satu satuan variabel, maka minat beli akan meningkat sebesar 0,129 kali satuan variabel, dengan syarat variabel $\mathrm{X}_{1}, \mathrm{X}_{3}$ dan $\mathrm{X}_{4}$ tetap, dan apabila variabel membu- 
juk/mempengaruhi dimisalkan nol (tetap), maka variabel minat beli tetap ada sebesar konstanta 0,913.

Dari persamaan diatas dapat diartikan bahwa besarnya pengaruh menciptakan kesan $\left(X_{3}\right)$ terhadap minat beli sebesar 0,192 , ini berarti apabila variabel menciptakan kesan ditingkatkan sebesar satu satuan variabel, maka minat beli akan meningkat sebesar 0,192 kali satuan variabel, dengan syarat variabel $\mathrm{X}_{1}, \mathrm{X}_{2}$ dan $\mathrm{X}_{4}$ tetap, dan apabila variabel menciptakan kesan dimisalkan nol (tetap), maka variabel minat beli tetap ada sebesar konstanta 0,913.

Dari persamaan diatas dapat diartikan bahwa besarnya pengaruh memuaskan keinginan $\left(\mathrm{X}_{4}\right)$ terhadap minat beli sebesar 0,112 , ini berarti apabila variabel memuaskan keinginan ditingkatkan sebesar satu satuan variabel, maka minat beli akan meningkat sebesar 0,112 kali satuan variabel, dengan syarat variabel $\mathrm{X}_{1}, \mathrm{X}_{2}$ dan $\mathrm{X}_{3}$ tetap, dan apabila variabel memuaskan keinginan dimisalkan nol (tetap), maka variabel minat beli tetap ada sebesar konstanta 0,913.

\section{PEMBAHASAN}

Berdasarkan hasil penelitian yang menunjukan adanya pengaruh yang signifikan antara variabel-variabel fungsi dan arti periklanan terhadap variabel minat beli konsumen produk sabun mandi kecantikan, baik secara simultan maupun secara parsial.

Maka dapat dibuat pembahasan dari hasil penelitian tersebut. Dari hasil temuan dalam penelitian maka pihak produsen sabun mandi kecantikan bisa mengimplementasi beberapa strategi dalam periklanan, diantaranya:

a. Dengan informasi yang diperoleh dari sumber penelitian, sebaiknya jika perusahaan ingin membuat sebuah pesan iklan (informasi) yang didasarkan pada Consumer Decision Model (CDM), maka perlu memperhatikan seluruh variabel dengan lebih menekankan isi pesan dan struktur pesan yang didalamnya mengandung brand name exposuresehingga mampu menumbuhkan kesadaran konsumen, membangun identitas merek, membujuk (mempersuasif) konsumen, menumbuhkan atau membangun sikap yang diinginkan serta dapat menaikkan keyakinan konsumen.

b. Dampak dari adanya iklan yang diminati atau dievaluasi secara menguntungkan dapat menghasilkan sikap yang lebih positif terhadap produk, maka hal tersebut akan memberikan timbal balik atau keuntungan yang lebih besar bagi perusahaan. Sedangkan iklan yang tidak diminati dapat mengurangi minat dan dapat membentuk sikap yang negatif, sehingga hal ini dapat merugikan pihak perusahaan. Oleh karena itu perusahaan perlu lebih selektif dalam memberikan informasi, sebab pesan iklan (informasi) mengacu pada proses yang dengannya suatu stimulus diterima, ditafsirkan, disimpan dalam ingatan dan diambil kembali (recall) yang dibentuk dalam tahapan proses.

c. Adanya persaingan antar perusahaan dapat mengalihkan perhatian konsumen, maka perusahaan harus memahami apa yang menjadi keinginan konsumen sehingga konsumen tidak beralih terhadap merek lain. Hal ini akan membentuk sikap dan kepercayaan konsumen dalam menentukan pilihan serta menumbuhkan minat beli. Dimana pembelian ada karena konsumen tersebut sudah mempunyai minat terlebih dahulu untuk membeli suatu produk, karena minat beli konsumen dibentuk dari sikap konsumen dan keyakinan konsumen dari kualitas produk.

d. Karena sikap konsumen terhadap iklan mempunyai dampak yang lebih kuat, maka perusahaan penting untuk mempertahankan sikap konsumen serta keyakinan konsumen terhadap merek dan maksud untuk membeli.

e. Lingkungan komunikasi yang berubah dikarenakan adanya pemasaran massal menjadi pertimbangan penting untuk merencanakan strategi berikutnya dalam menjalankan perusahaan dan produknya serta menjalin hubungan konsumen den- 
gan baik, sehingga masing-masing perusahaan dapat meningkatkan atau mempertahankan kinerja produknya pada strategi pemasaran bersaing. Jika perusahaan menyandarkan pada Consumer Decision Model (CDM).

Produsen sabun mandi kecantikan bisa juga meningkatkan kreativitas iklan produknya, dengan cara:

\section{Memperhatikan isi pesan}

Isi pesan dalam iklan sabun mandi kecantikan, mudah dipahami, tidak menyesatkan, tidak terkesan vulgar, dan yang terpenting sesuaikan dengan image dari produk. Sehingga masyarakat yang melihat iklan paham akan maksud isi pesan iklan yang disampaikan. Sehingga Setelah menyaksikan iklan melalui media televisi masyarakat memutuskan untuk membeli produk sabun tersebut.

2. Memperhatikan struktur pesan

Argumentasi, urutan penyajian iklan mandi kecantikan dan letak kesimpulan pesan diusahakan bagus, tepat, dan tidak berbelit-belit.Sehingga Setelah menyaksikan iklan sabun melalui media televisi masyarakat mempunyai keinginan untuk membeli produk sabun.

3. Memperhatikan format pesan Latar belakang suara, musik, gambar, warna, akting dan dialog dalam iklan sabun mandi kecantikan harus bagus disesuaikan dengan image produk.Sehingga Setelah menyaksikan iklan melalui media televisi masyarakat tertarik pada produk sabun tersebut.

4. Memilih sumber pesan

Bintang iklan dalam iklan sabun mandi kecantikan adalah orang yang tepat, menarik dan meyakinkan, kalau bisa orang yang tidak cacat hukum ataupun asusila.Karena berpengaruh terhadap image dari iklan dan produk yang dijual.

5. Menetapkan waktu penayangan

Waktu dan frekuensi penayangan iklan sabun mandi kecantikan pada media elektonik televisi harus tepat, di usahakan pada jam-jam tayang yang banyak ditonton, seperti jam 19.00-22.00, dimana pada jam tersebut banyak orang menonton televisi. Sehingga partisipasi masyarakat tinggi terhadap iklan.

\section{SIMPULAN}

Dari tabel Model Summary menunjukan variabel fungsi dan arti periklanan menjelaskan variabel minat beli konsumen sebesar $54,9 \%$, sedangkan sisanya sebesar $45,1 \%$ dipengaruhi oleh variabel/faktor di luar penelitian, dimana nilai $\mathrm{R}=0,741$.

Nilai signifikan variabel fungsi dan arti periklanan terhadap minat beli secara simultan menunjukan nilai sig. 0,000 (< $0,05)$ pada tingkat $\alpha=5 \%$. Hal ini menunjukan bahwa terdapat pengaruh yang signifikan antara variabel independent terhadap variabel dependent penelitian secara simultan.

Nilai signifikan variabel fungsi dan arti periklanan terhadap minat beli secara parsial menunjukan nilai $<0,05$ pada tingkat $\alpha=5 \%$. Hal ini menunjukan bahwa terdapat pengaruh yang signifikan antara variabel independent terhadap variabel dependent penelitian secara parsial.

\section{DAFTAR RUJUKAN}

Arikunto, Suharsimi. 2002. Prosedur Penelitian Suatu Pendekatan Praktek. Rineka Cipta. Jakarta.

David, Loudon and Albert J. Della Bitta. 1993. Consumer Behavior Concept and Application. Penerbit Mc Grow Hill Book. Co.

Djarwanto, PS dan Subagyo.Pangestu. 1993. Statistik Induktif. BPFE.Yogyakarta.

Engel, James F. Roger D. Black Well, Paul W. Miniard. 1994. Perilaku Konsumen. Binarupa Aksara. Jakarta.

Hadi, Sutrisno. 2000. Metodologi Research. Andi Offset. Yogyakarta.

Kasali, Rhenald. 1995. Manajemen Periklanan Konsep dan Aplikasinya Di In- 
donesia.PT Pustaka Utama Grafiti. Jakarta.

Kotler, Philip dan Armstrong, Gary. 1997. Dasar-Dasar Pemasaran, Prehallindo. Jakarta.

Stanton, William. 1978. Fundamental of Marketing. Graw-Hill Book Company. Tokyo.

Surachmand, Winarno. 1995. Dasar dan Teknik Research. Bumi Aksara. Jakarta.

Susanti, Esti. 2003. Analisis Persepsi Konsumen Terhadap Kualitas Produk Keramik Merek Milan di Surabaya. Jurnal Widya manajemen \& Akuntansi, Vol. 3, No.2, Agustus 2003, Universitas Katholik Widya Mandala. Surabaya.

Susila, Ikhwan dan Fatkhurrahman. 2004. Service Value: Sebuah Variabel Pemediasi Pengaruh Kualitas Pelayanan terhadap Minat Beli. Empirika, Vol. 17, No.1 Juni 2004.

Sutisna dan Pawitra.2001. Perilaku Konsumen dan Komunikasi Pemasar. Remaja Rosdakarya. Bandung.

Swastha, Basu dan Irawan. 1997. Manajemen Pemasaran Modern. Liberty. Yogyakarta.

Yamit, Zulian. 2001. Manajemen Kualitas Produk dan Jasa.Ekonomi.Yogyakarta. 